てはめていくことが必要である。

（3）トップスライシング採掘法の合理化 自走支保 の採用，人工天盤の工夫を適当に組合せて支保関倸を合 理化すること。さく孔時間の短縮, 切羽運般の能率化に ついて改善すべきことなどが課題である。

（4）細脈採掘 鉱楼鉱床の周辺や，下部について は，幅 $20 \mathrm{~cm}$ 前後の細脈が存在するが，これを能率良く 採掘するには，現在のストリッピング法を再検討する必 要がある。

（5）沈殿銅採収 仕上り原価がきわ放めて低廉なるこ とや，現在の採掘法で，採算限界点以下である低品位鉱 体について，溶銅採収が望ましいことなどにより，溶銅 リーチングを促す種々の手段が検討されている。その中

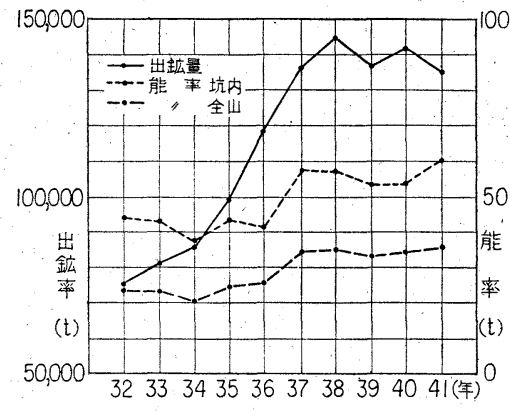

第 5 図

に強制散水があるが，これを採掘切羽に支障なく、併行し て有効飞行なう必要がある。

\title{
鰐淵鉱出
}

\section{Wanibuchi Mine}

\section{1. 緒言}

鳄淵鉱山は島根県平田市河下町に所在し, 北は日本海 に面し, 出雲大社の北東約 $6 \mathrm{~km}$ の地点にある。

当鉱山の歴史は松江藩時代に遡るといわれるが昭和 12 年に昭和鉱業株式会社の経営となり現在におょんでい る。

元来，黒鉱の採掘を行なっていたが，終戦後これと並 行して石高を採掘するようになった。現在, 稼行の主体 は石膏でめり，その生産量は国内の約 30\%を占めてい るc

第 1 表 粗鉱量と出鉱品位

\begin{tabular}{|c|c|c|c|c|c|c|}
\hline \multirow{2}{*}{ 鉱 } & \multirow{2}{*}{ 種 } & \multirow{2}{*}{$\begin{array}{c}\text { 粗節量 } \\
(\mathrm{t})\end{array}$} & \multicolumn{2}{|c|}{ 品 } & \multicolumn{2}{|c|}{$(\%)$} \\
\hline & & & $\mathrm{SO}_{3}$ & $\mathrm{Cu}$ & $\mathrm{Zn}$ & $\mathrm{Pb}$ \\
\hline 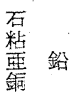 & $\begin{array}{l}\text { 裔 } \\
\text { 犎 } \\
\text { 鉱 }\end{array}$ & $\begin{array}{r}16,595 \\
234 \\
432 \\
128\end{array}$ & $\begin{array}{r}33.89 \\
=\end{array}$ & $\begin{array}{r}\overline{-} \\
2 . \overline{13} \\
5.91\end{array}$ & $24 . \overline{98}$ & $5 . \overline{54}$ \\
\hline
\end{tabular}

第 2 表 従業員 (探查，採鉱，選鉱） (42年 3 月末現在)

\begin{tabular}{|c|c|c|c|c|}
\hline & 坑 & 内 & 坑 & 計 \\
\hline 職 & & $\begin{array}{r}18 \\
279 \\
52 \\
349\end{array}$ & $\begin{array}{r}2 \\
17 \\
13 \\
32\end{array}$ & $\begin{array}{r}20 \\
296 \\
65 \\
381\end{array}$ \\
\hline
\end{tabular}

* 昭和㻌業株式会社鮕牀釭業所

\section{正会員土田房 雄 ${ }^{*}$ Fusáo TSUCHIDA}

\section{2. 地質鉱床の概要}

付近の地質は新第三紀中新世㳊属する緑色凝灰岩, 頁 岩, 砂岩等の累層からなり, 安山岩, 石英粗面岩なぞの 火成岩の迸入をみる。鉱山付近の地層の一般走向は大体 東西方向で，傾斜は北落しである。

鉱床は黒鉱式の浅熱水性鈗床に属し，黑鉱々石亮に大 別され，頁岩中またはそれと緑色凝灰岩との境界付近に 両者玉たは一方を交代して賦存する。鉱体はレンズ状ま たは塊状を呈し，規模は大小様々である。

現在主に稼行しているのは第 3 鈗体と金山沢東鉱体で 岁る。第 3 鈗体怯走向延長 $250 \mathrm{~m}$, 傾斜延長 $450 \mathrm{~m}$, 厚さ 10 40m (平均約 $25 \mathrm{~m}$ ) のレンズ状で走向 $\mathrm{N} 75^{\circ} \mathrm{E}$, 傾 斜 $40 \sim 45^{\circ} \mathrm{N}$ である。金山沢東鉱体は走向延長 $300 \mathrm{~m}$, 傾 斜延長 $250 \mathrm{~m}$ 以上, 厚さ $5 \sim 20 \mathrm{~m}$ (平均 $15 \mathrm{~m}$ ) のレンズ 状で，走向 $\mathrm{E} \sim \mathrm{W}$, 傾斜約 $30^{\circ} \mathrm{N}$ である。

黒鉱鉣床は見掛上石高鈗床の上盤側飞位置するが，石 簑鉣床中に存在することもまれにある。

第 3 表 開探鉣出鉣量抎よび試錐趧長

\begin{tabular}{|c|c|c|c|c|c|}
\hline & \multirow{2}{*}{$\begin{array}{c}\text { 試錐狿長 } \\
(\mathrm{m})\end{array}$} & \multirow{2}{*}{$\begin{array}{c}\text { 探鉱延長 } \\
(\mathrm{m})\end{array}$} & \multicolumn{3}{|c|}{ 鉱 量 $(\mathrm{t})$} \\
\hline & & & 開探鉱 & 採 鉱 & 計 \\
\hline 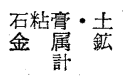 & $\begin{array}{l}293 . \overline{95} \\
293.95\end{array}$ & $\begin{array}{l}40.9 \\
38.0 \\
78.9\end{array}$ & $\frac{686}{686}$ & $\begin{array}{r}16,143 \\
560 \\
16,703\end{array}$ & $\begin{array}{r}16,829 \\
560 \\
17,389\end{array}$ \\
\hline
\end{tabular}




\section{3. 採 掘 法}

\section{$3 \cdot 1$ 採掘法の概要}

水平運般坑道は原則として上下レベル間隔 $25 \mathrm{~m} て ゙$ 開さ くし，上盤沿い拉よび下盤沿いに銿押掘進した上盤坑道 と下盤坑道ならびに上盤坑道と下盤坑道を連絡する立入 坑道からなる。

採掘の方法はカットアンドフィル法とシュリンケージ 法に大別され，カットアンドフィル法は水平上向，斜上 向，括上び斜前進式に分類される。それぞれの方法は鉱 体および鉙画の性質, 形状, 付近の状況に応じて適用さ れる。

切羽は上下運般坑道間 $25 \mathrm{~m}$ 亿鉱体の走向とほ涪直角に 設定する。切羽の幅はそそれぞれの採掘法で規制されてい るが招括むね $4 \mathrm{~m}$ 以下，切羽延長は鉱体の厚さにより決

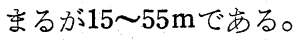

な怙石膏鉱体の特質としてレンズ状〜塊状の大きな鉱 体であるが強度が小さく採掘が進展するにつれて多数の 龟裂を生じる傾向がある。これは採掘切羽を大型化でさ ない险路となっている。

採掘法別の主要素を第 4 表に示し，その方法について は種々変型があるがそれぞれの模範的なものを $3 \cdot 2$ 項か ら 3.5 項代記す。

第 4 表 採掘法別主要素

\begin{tabular}{|c|c|c|}
\hline & カットアンドフィル法 & 半長孔シュリンケージ法 \\
\hline せん孔機 & \begin{tabular}{|c|} 
TY-16LD, TY-20LD \\
TY-24LD, TY-75LD \\
ロッド: $22 \mathrm{~mm} \phi$ ○鋼 \\
ビット: $32 \sim 38 \mathrm{~mm} \phi \mathrm{WC}$ \\
AAL-2 オーガードリル \\
ロッド: $30 \mathrm{~mm} \phi$ \\
ビット: $38 \mathrm{~mm} \phi$ \\
オーガービット
\end{tabular} & \begin{tabular}{|c} 
左記の他, TY-145 \\
ライトドリフタ \\
ロッド: $22 \mathrm{~mm} \phi$ ○ी 鋼 \\
ビット: $42 \mathrm{~mm} \phi \mathrm{WC}$ \\
$\mathrm{BP}-3$ ポータブルボーラー \\
ロッド: $38 \mathrm{~mm} \phi$ \\
スパイラルロッド \\
ビット: $42 \mathrm{~mm} \phi$ \\
オーガービット
\end{tabular} \\
\hline 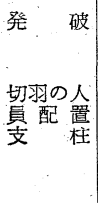 & $\begin{array}{l}\mathrm{H} \cdot \mathrm{S} \text { 電気雷管 } \\
3 \text { 号桐ダイナマイト, AN-FO } \\
\text { 爆薬 } \\
\text { 支柱作業 } 2 \text { 名, 他 } 1 \sim 2 \text { 名 } \\
\text { 必要に応じて三留枠カチ込等 } \\
\text { グランビーカーまたは木製鉱車 } \\
\text { スラッシャによりスラッシング }\end{array}$ & $\begin{array}{l}\mathrm{H} \cdot \mathrm{S} \text { 電気雷管, 蕆爆薬 } \\
3 \text { 号桐ダイナマイト, AN-FO } \\
\text { 爆薬 } \\
\text { 支柱, さく岩作業 } 2 \text { 名他 1〜2名 } \\
\text { 必要に応じてカチ込み } \\
\text { でズリを充井に投入, 切羽では }\end{array}$ \\
\hline
\end{tabular}

\section{2 水平下向充塥採掘法}

残柱採掘や岩盤が脆弱な個所の採掘に主として採用す る。これは切羽面が水平であるので岩盤点検や切羽支保 を確実に行ない得るからである。

採据準備として上, 下艋坑道を結ぶ立入坑道を切羽幅 で掘進しこ礼を第 1 スライスとする。区画内上盤沿いに 充井を切上げる。切羽面を水平保らながら 1 スライス 1.6 2.0mごとに採掘と充填を行なう。3 スライス汪ど 採掘が進行したとき下盤坑道側化切羽鉱井を設ける。

採掘作業はさく鉱, 搬出, 支保がいる場合は支柱を交互

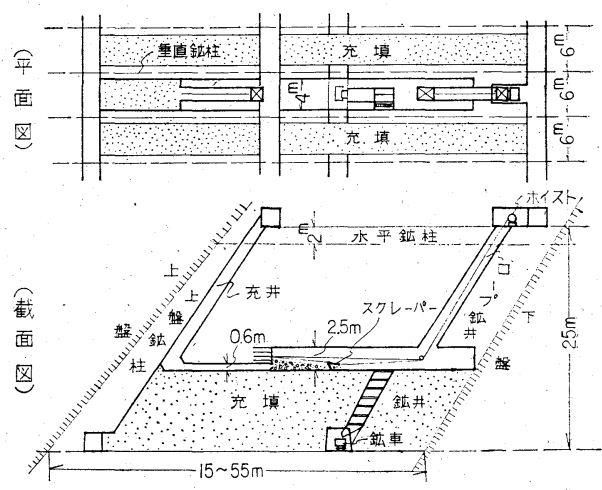

第 1 図 水平上向充垻採掘法
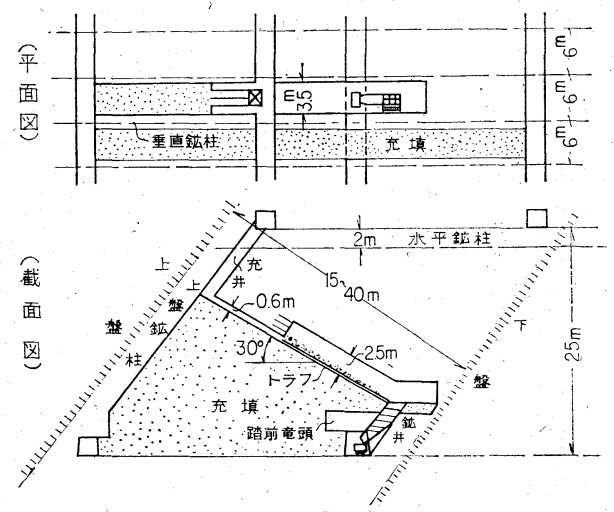

第 2 図 斜上向充填採掘法

に行なう。さく岩は長さ1. 2 1. $5 \mathrm{~m}$ で10〜 20本水平に穿 孔乙装薬して電気発破する。1 スライスの採掘が終了す ると予定充填高さまで木造鉣井を組上げて充埧を行なう。 起砕鈗石扣よび充填ズリの搔出しはスラッシャで行な 万。切羽の大様を第 1 図に示す。

\section{$3 \cdot 3$ 斜上向充晴採掘法}

本採掘法は切羽面に $35^{\circ}$ 以下の傾斜斿る。傾斜を

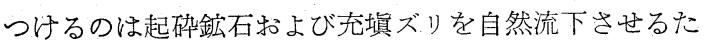
めである。採掘幅は $3 \sim 4 \mathrm{~m}$ が普通である。

採掘時に充填ズリ面には $3.2 \mathrm{~mm}$ 厚鉄板トラフを敷き 並べてここの上を滑らせるか，またはスラッシャで搔さ 込久を行なう。充填ズリ面から天盤までの距離は $2.5 \mathrm{~m}$ 以下を原則としている。さく岩は進行長 $1.2 \sim 2.0 \mathrm{~m}$ の段 欠かまたは切羽全面発破を行なう。

本法は岩盤が比較的堅固な一次採掘汇適用されるので 支柱は湾とんどいらない。また充填面に傾斜をつけるの で切羽内運般費が安くすむ。切羽の大様を第 2 図に示 す。

\section{$3 \cdot 4$ 斜前進式充填採掘法}

水平上向法执よび斜上向法は, 鉱体傾斜が $30^{\circ}$ ぐらい に緩くなると鈗井拉よび充井が安息角の制約をうけて不 

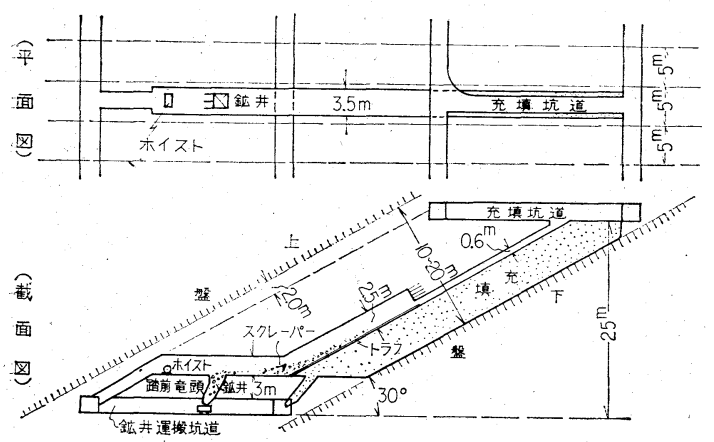

第 3 図斜前進式採掘法

利な場合がある。本法はこのような箇所洫用されるる ので，斜上向法とは逆注鉱体傾斜と平行するよう切羽 を設定する。他汇斜上向法と異なることは正式の充井お よび鉱井が不要であること, 充井口と鉱井漏斗は逐次上 盤側洺行するなどである。

採掘および充填作業はほぼ斜上向法と同様である。な 扣漏斗の移動を避祆るために踏前竜頭 $3 \sim 5 \mathrm{~m}$ を残す位 置でサブレベルを開さくし，この竜頭内に切羽鉱井を設 けることがある。これを第 3 図渎す。

\section{$3 \cdot 5$ 半長孔シュリンケージ採掘法}

本採据法は昭和 39 年以来試験操業を続けて現在汇至っ たものであり，4つの採掘法の中で最も能率が高い。

切羽は鉱体走向と直角方向偪 $3.0 \mathrm{~m}$ で設定する。採 掘準備として下盤沿いに下盤鉱井を切上げ，上盤側から 踏前竜頭 $5 \sim 6 \mathrm{~m}$ 残す位置まで上盤鉱井を切上げここか

第 5 表：採掘法別出鉱量拈よび切羽数

（42年 3 月実績）

\begin{tabular}{|c|c|c|c|c|c|}
\hline 種 & 採 & 掘 & \begin{tabular}{|l|}
$\mid$ 粗鉱出筀 \\
量 $(\mathrm{t})$
\end{tabular} & $\mid \begin{array}{c}\text { 出鉣比率 } \\
(\%)\end{array}$ & 切羽数 \\
\hline 石育・粘土 & 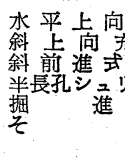 & $\begin{array}{l}\text { 充填採掘 法 } \\
\text { 填採掘 法 } \\
\text { 充填採摡 法 } \\
\text { ンケ棌掘法 } \\
\text { の 採 } \\
\text { 計 }\end{array}$ & $\begin{array}{r}10,388 \\
3,660 \\
98 \\
780 \\
1,903 \\
16,829\end{array}$ & $\begin{array}{r}61.7 \\
21.8 \\
-6.6 \\
4.6 \\
11.3 \\
100\end{array}$ & $\begin{array}{r}42 \\
9 \\
1 \\
11 \\
63\end{array}$ \\
\hline 金属 鉱 & 進 & 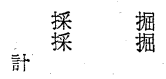 & $\begin{array}{r}83 \\
477 \\
560\end{array}$ & $\begin{array}{r}14.8 \\
852 \\
100\end{array}$ & $\begin{array}{r}4 \\
11 \\
15\end{array}$ \\
\hline
\end{tabular}

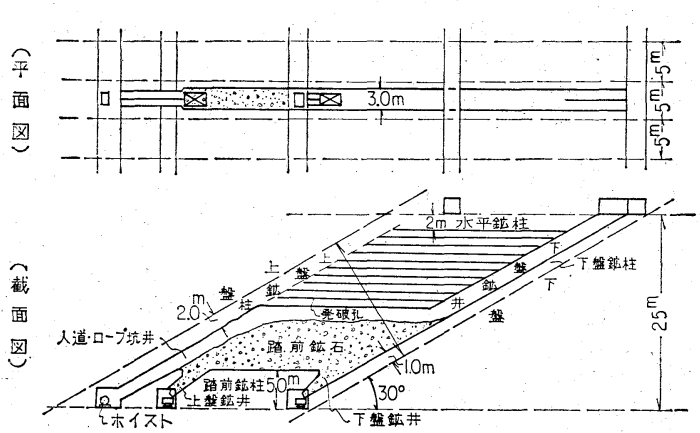

第4図半長孔ショリンケージ採掘法

ら下盤鉱井まで立入掘進してこれをサブレベルとする。 せん孔は下盤鈗井から横 $1.0 \mathrm{~m}$ 間隔, 縦約 $0.5 \mathrm{~m}$ 間隔に $0 \sim 5^{\circ}$ で上盤境界推定線の手前 $3 \mathrm{~m}$ まで長孔穿孔する。 せ九孔の上限は上部坑道の下 $2 \mathrm{~m}$ とする。

発破は $\mathrm{AN}-\mathrm{FO}$ 爆薬を主体にして装薬し導爆線を用い て電気発破する。1段ずつ長孔発破と小割発破を繰返し ながら上部に進んでいく。全部の発破が終了したときに あらかじめ上部レベル上盤坑道に充井を切上げて特く。

搬出作業は下盤扰よび上盤鉱井漏斗から鉱車に抜取る 一方, 切羽内では10IPまたは30I電動スラッシャで搔出 しを行なう。天盤と側壁の保持は般出途上で綿密な点検 を行ない随時カチ込み等の支柱を施こす。採掘準備から 採掘終了までの期間は呿执よそ $2 \sim 3$ 力である。

充填は充井からズりを投入してスラッシャで搔込み, 空間がないよ5にする。切羽の大様を第 4 図に示す。

\section{4. 運搬, 通気, 排水, 保安}

切羽運搬はスラッシャ, トラフ，コンベヤを使用する ほか手積を行なう。各切羽からの鉱石は $0.8 \mathrm{~m}^{3}$ 木製鉱車 または鉄製鉱車もしくは $0.8 \sim 1.2 \mathrm{~m}^{3}$ グランビー 鉣車に 積み, 中段運搬では手押, 主要運搬纣道ではバッテリロ コで運搬する。これら鈗石は上部地区では主要鉱井に， 下部地区では斜坑に集荷されて $-150 \mathrm{~L}$ 電車主要運搬坑 道で立坑に運ばれる。

第 6 表、採掘法別工程原単位特よび直接採掘, 採鉱費

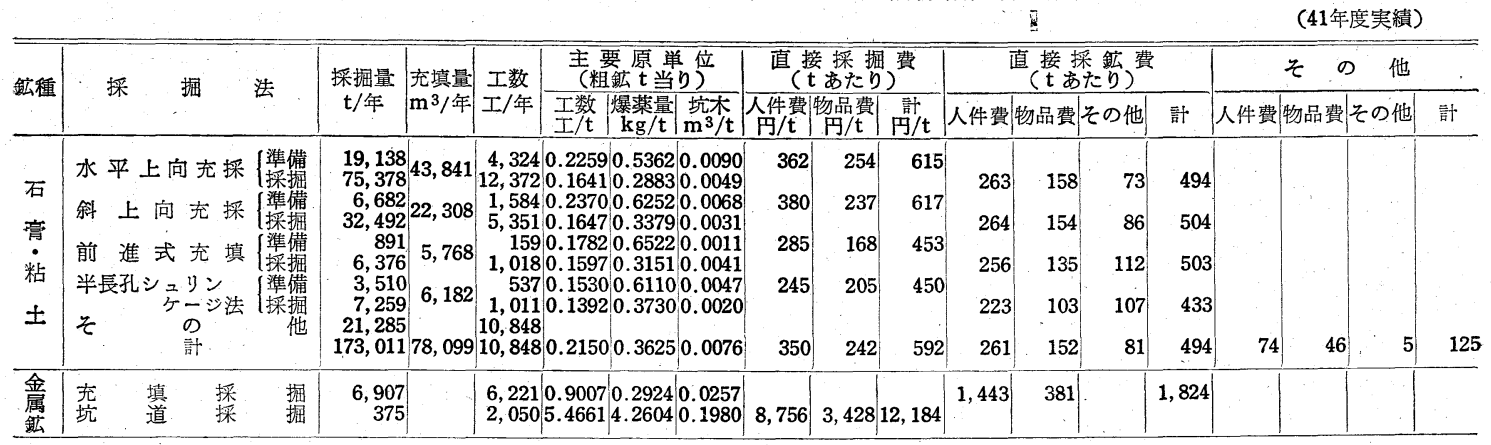


充填ズリはグローリーホール法で月に約 $4,000 \mathrm{~m}^{3}$ の安 山岩を起砕し充井を通して各レベルに供給している。

通気は立坑を入気としこれと別に開口する別所 $0 \mathrm{~L}$ 坑 道に22.5Pプロペラファン 2 台を据えて機械通気を行な って拉り各坑道の通気は比較的良好である。

涌水は立坑周辺の安山岩からのものが汪とんどであり

1 日の揚水量は約 $850 \mathrm{~m}^{3}$ である。

照明は坑内全域に電灯を設置して行ない，作業員はす ベてキャップランプを携带している。

保安の重点は落盤拈よび浮石落下, 墜落, 火薬類およ び発破等による災害防止においている。特に落盤および 浮石落下については母岩が軟弱でかつ鉱石も比較的軟弱 であり石目や夾在物があることから起き易い事故であり 最重点を和き綿密な点検, 早期の手当を行なつて炎害防 止につとめている。

\section{5. 問題点と将来計画}

鉱床が大きい割にはその特質から大型切羽を設けるに は制限がある。これと相まって比較的小規模な切羽が分 散する。このことから採掘能率は決して高いものではな い。機械化もスラッシャや電車の導入に止どまってお り，これら機械を大型化することには限度がある。盤圧 制御を考慮に入れて適正な密度で高能率の切羽を集約し
て設定する必要がある。

他にさしあたつて目標にしているのは木材の価格高騰” 入手難に対処するため鋼枠，コンクリート枠，鉄板鉣井 等の大幅な普及, 切羽設定準備には不可欠である切上掘. 進の改善, 他各種作業の簡素化などがある。

以上の改善に努め, 能率向上, 原価引下げを推進して いく考えである。

\section{6. 過去10年間の年間粗鉱量, 平均品位および 能率の推移}

(第 7 表, 第 5 図参照)

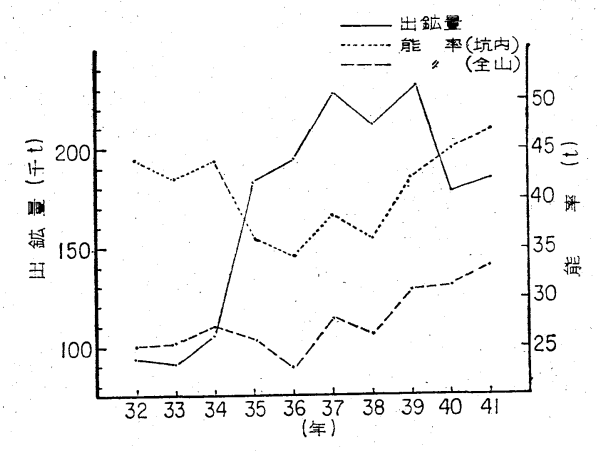

第 5 図

第 7 表

\begin{tabular}{|c|c|c|c|c|c|c|c|c|c|c|c|c|}
\hline \multirow{2}{*}{ 年度 } & \multicolumn{5}{|c|}{ 年間 粗 釷.出.鉱量 $(\mathrm{t})$} & \multicolumn{2}{|r|}{ 均 } & \multirow{2}{*}{ 属 } & \multicolumn{2}{|l|}{$\begin{array}{l}(\%) \\
\text { 铁 }\end{array}$} & \multicolumn{2}{|c|}{$\begin{array}{l}1 \text { 人 } 1 \text { 力月当出鉱量 } \\
(\mathrm{t})\end{array}$} \\
\hline & 石高・粘土 & '銅 & 鉱 & 亜 鉛 鉣 & 訫 & 吕 亳 & 銅 & & 鉛 & & 坑 内 & 全 山 \\
\hline $\begin{array}{l}32 \\
33 \\
34 \\
35 \\
36 \\
37 \\
38 \\
39 \\
40 \\
41 \\
\text { 計 }\end{array}$ & $\begin{array}{r}93,680 \\
91,081 \\
105,751 \\
183,833 \\
194,965 \\
229,683 \\
212,481 \\
227,645 \\
172,155 \\
179,308 \\
1,690,582\end{array}$ & & $\begin{array}{l}1,217 \\
2,180 \\
1,643 \\
5,040\end{array}$ & $\begin{array}{r}1,538 \\
3,445 \\
5,264 \\
10,247\end{array}$ & $\begin{array}{r}93,680 \\
91,081 \\
105,751 \\
183,833 \\
194,965 \\
229,683 \\
212,481 \\
230,400 \\
177,780 \\
186,215 \\
1,705,869\end{array}$ & $\begin{array}{l}35.32 \\
35.76 \\
35.50 \\
34.98 \\
35.70 \\
34.71 \\
35.00 \\
34.90 \\
34.89 \\
34.69\end{array}$ & $\begin{array}{l}9.71 \\
9.76 \\
5.27\end{array}$ & $\begin{array}{l}22.16 \\
26.01 \\
22.44\end{array}$ & $\begin{array}{l}6.90 \\
6.70 \\
6.10\end{array}$ & $\begin{array}{l}1.75 \\
2.28 \\
1.99\end{array}$ & $\begin{array}{l}43.9 \\
41.9 \\
43.9 \\
35.9 \\
34.3 \\
38.3 \\
36.1 \\
42.2 \\
45.0 \\
47.1\end{array}$ & $\begin{array}{l}25.2 \\
25.4 \\
27.1 \\
25.7 \\
22.7 \\
28.1 \\
26.3 \\
30.9 \\
31.3 \\
33.4\end{array}$ \\
\hline 平均 & 169,058 & & 504 & 1,025 & 170,587 & 34.86 & 7.43 & 23.60 & 6.43 & 2.05 & 39.9 & 27.6 \\
\hline
\end{tabular}

